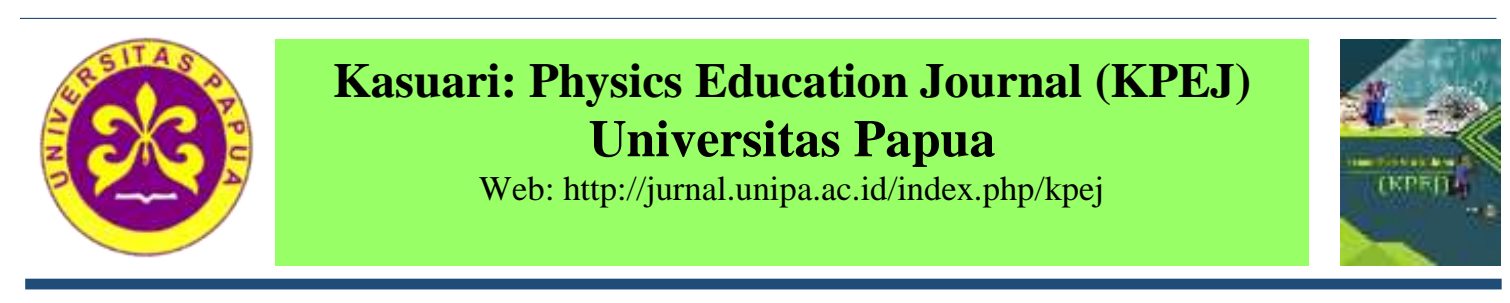

\title{
Effectiveness of Physics Teaching Material based on Contextual Static Fluid Material
}

\author{
Tri Ariani* \& Yaspin Yolanda \\ Program Studi Pendidikan Fisika, STKIP PGRI Lubuklinggau \\ *triariani.ta@gmail.com
}

\begin{abstract}
This study aims to determine the learning outcomes of class XI students in Lubuklinggau 6 Model State Senior High School 2018/2019 Academic Year after using contextual-based Physics teaching material for Static Fluid students and to find out the students' response to learning using contextual learning material Static Fluid class XI students in high school Negeri 6 Lubuklinggau Model 2018/2019 Academic Year. The sample of this study consisted of 23 students of class XI IPA 4 of State Senior High School 6 Model Lubuklinggau. Data collection is done by interview techniques, questionnaires, tests, and observations. The overall percentage of teaching material components is $81.82 \%$ (very good). The percentage of student responses to contextual-based teaching materials is $79.78 \%$ (very good). In addition, from the results of daily test results, the effectiveness percentage of $86.95 \%$ (very good) of students who received scores above 70 out of 10 test items. Data analysis technique used was $t$-test Calculated value $>t$ table with the value of t count $=3.69$ and $t$ table $=1.717$. The results of the average percentage of students in the affective realm of $89.40 \%$ (very good) and the results of the average percentage of students in the psychomotor realm of $91.30 \%$ (very good). The percentage of student responses to learning using contextual learning is $91.07 \%$ (very good). So that the use of contextual based teaching materials can be said to be valid, practical and effective.
\end{abstract}

Keywords: Effectiveness, Static Fluid Teaching Materials, Contextual Learning.

\section{Efektivitas Bahan Ajar Fisika berbasis Kontekstual pada Materi Fluida Statis}

\begin{abstract}
Abstrak: Penelitian ini bertujuan untuk mengetahui hasil belajar siswa kelas XI SMA 6 Model Lubuklinggau tahun akademik 2018/2019 setelah menggunakan bahan ajar Fisika berbasis kontekstual pada materi Statis dan untuk mengetahui respon siswa terhadap pembelajaran menggunakan bahan ajar berbasis kontektual. Sampel dalam penelitian ini terdiri dari 23 siswa kelas XI IPA 4 SMA Negeri 6 Model Lubuklinggau yang diambil secara acak dengan teknik simple random sampling. Pengumpulan data dilakukan dengan teknik wawancara, kuesioner, tes, dan observasi. Instrumen yang digunakan lembar observasi,angket, dan soal essay. Persentase keseluruhan komponen bahan ajar adalah 81,82\% (sangat baik). Persentase tanggapan siswa terhadap bahan ajar berbasis kontekstual adalah 79,78\% (sangat baik). Selain itu, dari hasil hasil tes harian, persentase efektivitas $86,95 \%$ (sangat baik) dari siswa yang menerima skor di atas 70 dari 10 item tes. Teknik analisis data yang digunakan menggunakan uji-t. Nilai yang dihitung $>\mathrm{t}$ tabel dengan nilai $\mathrm{t}$ hitung $=3,69$ dan $\mathrm{t}$ tabel $=1,717$. Hasil persentase rata-rata siswa di ranah afektif $89,40 \%$ (sangat baik) dan hasil persentase rata-rata siswa di ranah psikomotorik sebesar 91,30\% (sangat baik). Persentase respon siswa terhadap pembelajaran menggunakan pembelajaran kontekstual adalah 91,07\% (sangat baik). Sehingga penggunaan bahan ajar berbasis kontekstual dapat dikatakan valid, praktis dan efektif.
\end{abstract}

Kata kunci: Efektivitas, Bahan Ajar Cairan Statis, Pembelajaran Kontekstual 


\section{PENDAHULUAN}

Undang-Undang Nomor 20 Tahun 2003 tentang Sistem Pendidikan Nasional, Pasal 1 No. 1 menyatakan bahwa pendidikan adalah usaha sadar dan terencana untuk mewujudkan suasana belajar dan proses pembelajaran agar peserta didik secara aktif mengembangkan potensi dirinya untuk memiliki kekuatan spiritual keagamaan, pengendalian diri, kepribadian, kecerdasan, akhlak mulia, serta keterampilan yang diperlukan dirinya, masyarakat, bangsa dan negara (Widyaningsih, S. W., \& Yusuf, I., 2018: 12). Sesuai dengan visi pendidikan nasional yaitu terwujudnya sistem pendidikan sebagai pranata sosial yang kuat berwibawa dan berkualitas sehingga mampu menjawab tantangan jaman yang selalu berubah, maka mutu pendidikan harus ditingkatkan dan diselenggarakan secara efektif, artinya Kegiatan Belajar Mengajar (KBM) dapat berjalan secara lancar, terarah dan sesuai dengan tujuan pembelajaran. Tujuan pembelajaran tersebut dapat tercapai bila guru dapat menjalankan fungsinya dengan baik, guru sebagai fasilitator sehingga guru dapat menggunakan kesempatan yang ada sebaik-baiknya untuk proses pembelajaran yang efektif. Kriteria kegiatan belajar mengajar yang efektif: (1) kegiatan belajar mengajar mampu mengembangkan konsep generalisasi serta bahan abstrak menjadi hal yang mudah dimengerti (2) kegiatan belajar mengajar dapat melayani dan diterima dengan kemampuan belajar yang berbeda-beda, dan (3) kegiatan belajar mengajar melibatkan peserta didik aktif pada proses pembelajaran sehingga kegiatan belajar mengajar mampu mencapai tujuan sesuai program yang telah diterapkan. Peserta didik yang aktif dan kreatif didukung fasilitas serta guru yang menguasai materi dan strategi penyampaian secara efektif akan semakin menambah kualitas KBM. Dalam pendidikan di sekolah, berhasil tidaknya pendidikan tidak hanya ditentukan oleh proses belajar mengajar yang telah dilakukan tetapi ditentukan juga oleh guru sebagai media dan fasilitator pembelajaran. Guru menjadi pemimpin belajar yang memberi fasilitas belajar dan lingkungan yang kondusif yang memungkinkan siswa untuk belajar dengan nyaman. (Gumay, O. P. U., Kodarsih, E., \& Mulyanto, A. B, 2016: 40).

Salah satu mata pelajaran yang diajarkan dalam pendidikan formal di sekolah adalah Fisika. Fisika merupakan ilmu yang mempelajari tentang fenomena gejala alam dan tak lepas dari penerapan kehidupan sehari-hari. Fisika juga merupakan ilmu universal yang mendasari perkembangan teknologi modern dan mempunyai peran penting dalam berbagai disiplin ilmu dan mengembangkan daya pikir manusia. Untuk menguasai dan meciptakan teknologi dimasa depan diperlukan penguasaan konsep-konsep Fisika sejak dini dan dilakukan suatu tindakan yang terencana. Oleh karena itu, Fisika berperan mempersiapkan siswa atau generasi penerus agar dapat menghadapi tantangan-tantangan di kehidupan yang semakin berkembang dan modern. Persiapan-persiapan yang tersebut dilakukan dengan membekali siswa kemampuan berpikir logis, mengembangkan, pemahaman konsep, sistematis, mandiri, dan kreatif, serta kemampuan menerapkan aplikasi dalam kehidupan sehari-hari dari teori dan bekerja sama dalam pemecahan masalah (Fahrudin, A, 2018: 22-23).

Jhonson (2009: 32) mendefinisikan CTL adalah sebuah sistem yang menyeluruh. CTL terdiri bagian-bagian-bagian yang saling berhubung, jika bagian-bagian ini terjalin suatu sama lain, maka akan dihasilkan pengaruh yang melebihi hasil yang diberikan bagianbagian secara terpisah. CTL adalah konsep belajar dimana guru menghadirkan dunia nyata kedalam kelas dan mendorong siswa membuat hubungan antara pengetahuan yang dimiliki dengan penerapannya dalam kehidupan mereka sehari-hari, sementara siswa memperoleh pengetahuan dan keterampilan dari konteks yang terbatasi sedikit demi sedikit dan dari proses mengkonstruksi sendiri sebagai bekal untuk memecahkan masalah dalam kehidupannya sebagai anggota masyarakat. Dengan pembelajaran kontekstual ini 
maka siswa akan berkerja dan mengalami, bukan transper pengetahuan dari guru kesiswa semata. Strategi lebih dipentingkan dari pada hasilnya. Sehingga pengetahuan dan keterampilan yang diperoleh datang dari proses penemuan sendiri dan bukan kata guru.

Alasan perlu diterapkan pembelajaran kontekstual berdasarkan definisi Fisika merupakan ilmu yang mempelajari tentang gejala alam sehingga pembelajaran kontekstual sangat cocok sekali dalam mata pelajaran Fisika karena pembelajaran kontekstual merupakan konsep belajar yang membantu guru mengaitkan antara materi yang diajarkan dengan situasi dunia nyata dan dapat mendorong siswa membuat hubungan antara pengetahuan yang dimiliki dan penerapannya dalam situasi nyata yakni dalam kehidupan sehari-hari sehingga pemahaman konsep Fisika yang melibatkan keterlibatan siswa secara aktif baik fisik maupun mental akan mendapatkan hasil belajar siswa (Afriani, A, 2018).

Perkembangan suatu era globalisasi dan kualitas peradaban, tidak akan lagi disadarkan pada kekuatan sumber daya alam secara utuh melainkan sangat diperlukan manusiamanusia yang mampu mengembangkan suatu produk atau komponen penting dalam pelaksanaan pembelajaran yaitu melalui suatu pengembangan buku ajar (Yolanda, Y., \& Amin, A, 2018). Buku ajar merupakan komponen penting dalam pembelajaran. Buku ajar yang disampaikan oleh seorang guru hendaknya mengacu kepada tujuan yang telah digariskan dalam kurikulum. Selain itu, bahan ajar idealnya juga sesuai dengan kondisi lingkungan setempat agar pembelajaran lebih bermakna. Oleh karena itu, guru mempunyai keleluasan untuk mengembangkan buku ajar yang akan disampaikan sejauh tidak menyimpang dengan tujuan.

Sumariato (2018:23) mendefinisikan buku ajar adalah sebuah karya tulis berbentuk buku dalam bidang tertentu, merupakan buku standar yang digunakan guru dan siswa dalam proses pembelajaran untuk maksud-maksud dan tujuan instruksional. Pratama dkk (2016: 90) menyatakan buku ajar merupakan media pembelajaran cetak yang dapat digunakan untuk memudahkan pendidik dan peserta didik guna meningkatkan kompetensinnya.

Fluida statis adalah ilmu yang mempelajari tentang zat alir dalam kondisi diam khususnya zat cair dan gas dan merupakan salah satu materi dalam mata pelajaran Fisika dalam setiap indikator mempunyai hubungan dalam kehidupan sehari-hari. Sehingga aplikasi penerapannya materi fluida statis ini sangat cocok dalam pembelajaran kontekstual, sehinggga materi sangat penting diajarkan secara optimal sehingga peserta didik bisa mengetahui penerapan dari kehidupan sehari-hari dari teori tersebut.

Alasan perlu diterapkan pembelajaran kontekstual berdasarkan definisi Fisika merupakan ilmu yang mempelajari tentang gejala alam sehingga pembelajaran kontekstual sangat cocok sekali dalam mata pelajaran Fisika karena pembelajaran kontekstual merupakan konsep belajar yang membantu guru mengaitkan antara materi yang diajarkan dengan situasi dunia nyata dan dapat mendorong siswa membuat hubungan antara pengetahuan yang dimiliki dan penerapannya dalam situasi nyata yakni dalam kehidupan sehari-hari sehingga pemahaman konsep Fisika yang melibatkan keterlibatan siswa secara aktif baik fisik maupun mental akan mendapatkan hasil belajar siswa.

Berdasarkan latar belakang yang diuraikan di atas tampak betapa pentingnya mengaplikasikan bahan ajar berbasis kontekstual yang telah dikembangkan dalam penyelesaian masalah belajar siswa. Harapannya dengan buku ajar berbasis kontektula ini hasil belajar fisika siswa meningkat. 


\section{LANDASAN TEORI \\ Pengertian Pembelajaran}

Pembelajaran merupakan inti dari proses pendidikan yang berbentuk komunikasi dua arah, yaitu antara peserta didik dengan pendidik serta antara peserta didik dalam rangka perubahan sikap. Komalasari (2010: 3) menyatakan pembelajaran merupakan suatu sistem atau proses membelajarkan subjek didik atau pembelajar yang direncanakan atau didesain, dilaksanakan, dan dievaluasi secara sistematis agar subjek didik atau pembelajar dapat mencapai tujuan-tujuan pembelajaran secara efektif.

Hosnan (2016: 18) menyatakan pembelajaran merupakan proses dasar dari pendidikan. Disanalah lingkup terkecil secara formal yang menentukan dunia pendidikan berjalan baik atau tidak. Berdasarkan uraian sebelumnya, maka dapat disimpulkan bahwa pembelajaran adalah proses interaksi yang dirancang, dilaksanakan, serta dievaluasi secara sistematis oleh guru untuk membuat siswa memahami dan mencapai tujuan pembelajaran sehingga terjadi perubahan perilaku siswa ke arah yang lebih baik.

\section{Pembelajaran Kontekstual}

Hosnan (2016: 267) menyatakan bahwa pembelajaran kontekstual merupakan konsep belajar dimana guru menghadirkan dunia nyata kedalam kelas dan mendorong siswa membuat hubungan antara pengetahuan yang dimilikinya dengan penerapanya dalam kehidupan sehari-hari. Yolanda (2014: 26) menyatakan sistem Contextual Teaching and Learning (CTL) merupakan proses pendidikan yang bertujuan membantu siswa melihat makna dalam bahan pekerjaan yang mereka pelajari dengan cara menghubungkan dengan konteks kehidupan mereka sehari-hari yaitu dengan konteks lingkungan, pribadinya, sosialnya, dan budayanya.

Berdasarkan beberapa definisi pembelajaran kontekstual tersebut dapat disimpulkan bahwa pembelajaran kontekstual adalah pembelajaran yang mengaitkan antara materi yang dipelajari dengan kehidupan nyata siswa sehari-hari, baik dalam lingkungan keluarga, sekolah, masyarakat maupun warga negara, dengan tujuan untuk menemukan makna materi tersebut bagi kehidupanya dan mempunyai tujuh komponen pembelajaran kontekstual yang membantu guru dalam melakukan kegiatan belajar mengajar karena setiap komponen tersebut sangat membantu sekali dalam proses belajar mengajar.

Sementara itu, Ditjen Dikdasmen (dalam komalasari, 2010: 11-12) menyebutkan tujuh komponen utama pembelajaran kontekstual, yaitu:

1. Konstruktivisme.

Konstruktivisme (constructivism) adalah proses atau menyusun pengetahuan baru dalam struktur kognitif peserta didik berdasarkan pengalaman pribadinya serta fase dilaksanakan pada menyampaikan suatu apersepsi kepada peserta didik sebelum melakukan proses belajar.

2. Menemukan (inquiry).

Menemukan (inquiry) adalah proses pembelajaran yang didasarkan pada pencarian dan penemuan melalui berpikir secara sistematis. Pengetahuan dan keterampilan yang diperoleh siswa diharapkan bukan hasil mengingat seperangkat fakta-fakta, melainkan hasil dari menemukan.

3. Bertanya (questioning).

Bertanya (questioning) adalah belajar hakikatnya bertanya dan menjawab, bertanya dapat dipandang sebagai refleksi dari keingintahuan setiap individu terhadap sesuatu yang baru. 
4. Masyarakat belajar (learning community).

Masyarakat belajar adalah kerja sama atau belajar bersama dan sebuah masyarakat atgau kelompok. Hal ini dapat melakukan menerapkan pembelajarn kelompok

5. Pemodelan (modelling).

Pemodelan adalah pembelajaran dengan memperagakan sesuatu serbagai contoh yang dapat ditiru oleh peserta didik. Dalam pembelajaran keterampilan atau pengetahuan tertentu ada model yang bisa ditiru

6. Refleksi (reflection).

Refleksi adalah proses pengendapan pengetahuan dan pengalaman dilakukan dengan cara mengurutkan kembali kejadian-kejadian peristiwa pembelajaean yang telah diprosesnya

7. Penilaian yang sebenarnya (authentic assesment)

Penilaian yang sebenarnya adalah proses yang dilakukan guru untuk mengumpulkan informasi tentang perkembangan belajar yang dilakukan oleh siswa.

\section{Efektivitas Pembelajaran}

Efektivitas berarti berusaha untuk dapat mencapai sasaran yang telah ditetapkan sesuai dengan kebutuhan yang diperlukan, sesuai pula dengan rencana, baik dalam penggunaan data, sarana, maupun waktunya atau berusahan melalui aktivitas tertentu baik secara fisik maupun non fisik untuk memperoleh hasil yang maksimal baik secara kuantitatif maupun kualitatif. Menurut Kamus Besar Bahasa Indonesia (KBBI) bahwa efektivitas adalah sesuatu yang memiliki pengaruh atau akibat yang ditimbulkan, manjur, membawa hasil dan merupakan keberhasilan dari suatu usaha atau tindakan, dalam hal ini efektivitas dapat dilihat dari tercapai tidaknya tujuan instruksional khusus yang telah dicanangkan.

Trianto (2009: 20) menyatakan bahwa suatu pembelajaran dikatakan efektif apabila memenuhi persyaratan utama keefektifan pengajaran, yaitu:

a. Presentasi waktu belajar siswa yang tinggi dicurahkan terhadap KBM.

b. Rata-rata perilaku melaksanakan tugas yang tinggi di antara siswa.

c. Ketetapan antara kandungan materi ajaran dengan kemampuan siswa (orientasi keberhasilan belajar).

d. Mengembangkan suasana belajar yang akrab dan positif.

Nurfaidah, dkk (2017: 112) menyatakan bahwa siswa dikatakan tuntas belajar secara individu jika persentase daya serap individu $>65 \%$. Sedangkan suatu kelas dinyatakan tuntas belajar secara klasikal jika > 80\% siswa yang telah tuntas. Jadi pembelajaran menggunakan buku ajar fisika berbasis kontekstual efektif terhadap hasil belajar siswa dilihat dari ketuntasan belajar, pembelajaran dapat dikatakan tuntas apabila $>80 \%$ dari jumlah siswa yang telah belajar dapat memperoleh nilai $\geq 70$.

Berdasarkan beberapa pendapat di atas, maka dapat disimpulkan efektivitas pembelajaran merupakan suatu usaha atau strategi yang melibatkan seluruh komponen pendidikan dalam mencapai tujuan pendidikan yang telah ditetapkan sebelumnya secara tepat. Berkaitan sesuatu yang memiliki pengaruh atau akibat yang ditimbulkan, manjur, membawa hasil dan merupakan keberhasilan dari suatu usaha atau tindakan. Dalam penelitian untuk mengukur keefektifan yaitu pada hasil belajar siswa pada nilai ulangan harian aktivitas belajar siswa pada rang kongnitig, afektif, psikomotor dan respon siswa terhadap pembelajaran kontekstual baik. Setelah pembahasan di atas, maka indikator efektivitas dalam penelitian ini adalah: hasil belajar mencapai ketuntasan KKM $\geq 70$ dengan persentase ketuntasan $>80 \%$ dan respon siswa terhadap penggunaan model pembelajaran kontekstual baik. 


\section{Hasil Belajar}

Proses belajar mengajar dilaksanakan dengan maksud untuk melakukan suatu perubahan pada diri siswa sebagai hasil belajar. Hasil belajar merupakan kemampuan yang diperoleh siswa setelah melalui kegiatan belajar. Dimyati dan Mudjiono (2006: 3) menyatakan Hasil belajar merupakan suatu interaksi antara tindakan belajar dan tindakan mengajar. Dari sisi guru, tindakan mengajar diakhiri dengan proses evaluasi hasil belajar. Sementara itu, Nashar (2004: 77) menyatakan Hasil belajar adalah kemampuan yang diperoleh siswa serta perubahan secara berkesinambungan, atau perubahan yang terjadi akan menyebabkan perubahan berikutnya dan berguna bagi kehidupan atau proses belajar berikutnya. Jihad \& Haris (2012: 15) menyatakan hasil belajar adalah perubahan tingkah laku siswa secara nyata setelah dilakukan proses belajar mengajar yang sesuai dengan tujuan pengajaran. Kasmadi \& Sunariah (2013: 44) menyatakan hasil belajar adalah perubahan tingkah laku yang diperoleh siswa setelah melakukan kegiatan belajar. Terjadinya perubahan perilaku tersebut dapat diamati dan diukur dalam bentuk perubahan pengetahuan siswa sebagai hasil belajar dan proses interaksi dengan lingkunganya yang diwujudkan melalui pencapaian hasil belajar.

Dalam penelitian ini hasil belajar yaitu kemampuan siswa pada ranah kognitif (pengetahuan), afektif (unjuk kerja), dan psikomotor (unjuk keterampilan) sebagai berikut:

a. Ranah Kognitif

Pada ranah kognitif merupakan ranah yang akan mengukur kemampuan siswa dalam segi pengetahuannya dan pada ranah ini hasil belajar melalui tes berupa soal berbentuk essay dan tipe soal yang dipakai $\mathrm{C}_{1}$ dan $\mathrm{C}_{4}$.

b. Ranah Afektif

Pada ranah Afektif penilaian berdasarkan sikap peserta didik pada saat melakukan praktikum serta pada ranah ini penilaian dinilai oleh observer dari program studi pendidikan Fisika yang memiliki kemampuan materi tersebut. Adapun indikator penilaianya adalah sikap ingin tahu, ketekunan, dan tanggung jawab.

c. Ranah Psikomotorik

Dalam penelitian ini, penilaian dalam ranah psikomotorik lebih menekankan kepada penilaian unjuk kerja dalam praktikum materi Fluida Statis dengan aspek yang dinilai mengamati percobaan, menggunakan alat percobaan, melakukan percobaan, merapikan alat percobaan, diskusi dengan kelompok, bekerjasama dalam kelompok, menuliskan jawaban LKS, menuliskan data percobaan dalam tabel pengamatan, mendengarkan penjelasan/ informasi guru, dan percaya diri dalam kegiatan pembelajaran.

\section{Respon Siswa Dalam Pembelajaran Kontekstual}

Menurut Baroh, 2010: 36, respon merupakan gerakan-gerakan yang terkoordinasi oleh persepsi seseorang terhadap peristiwa luar dalam lingkungan sekitar. Untuk mengetahui respon seseorang terhadap sesuatu dapat melalui angket, karena angket pada umumnya meminta keterangan tentang fakta yang diketahui oleh responden/yang mengenai pendapat atau sikapnya. Baroh (2010: 36) menyatakan bahwa indikator respon siswa yang akan dideskripsikannya meliputi:

a. Sikap siswa terhadap pelajaran fisika

b. Respon siswa terhadap cara guru mengajar

c. Respon siswa terhadap cara belajar fisika

d. Respon siswa terhadap proses pembelajaran dengan model pembelajaran

e. Sikap siswa terhadap fisika setelah mengikuti pembelajaran fisika dengan menggunakan model pembelajaran. 
Adapun indikator respon siswa yang ada dalam penelitian ini ditunjukkan dalam Tabel 1.

Tabel 1 Indikator Respon

\begin{tabular}{|c|c|c|c|}
\hline No & Aspek & Indikator & Pernyataan \\
\hline \multirow[t]{2}{*}{1.} & \multirow[t]{2}{*}{$\begin{array}{lr}\text { Sikap } & \text { siswa } \\
\text { terhadap } & \text { pelajaran } \\
\text { Fisika } & \end{array}$} & $\begin{array}{l}\text { Menunjukkan minat } \\
\text { terhadap pelajaran fisika }\end{array}$ & $\begin{array}{l}\text { Bahan ajar fisika membuat } \\
\text { saya senang untuk } \\
\text { mengikuti pelajaran. }\end{array}$ \\
\hline & & $\begin{array}{l}\text { Menunjukkan manfaat } \\
\text { mempelajari fisika }\end{array}$ & $\begin{array}{l}\text { Dengan adanya bahan ajar } \\
\text { fisika, konsep pelajaran } \\
\text { dapat saya ingat lebih lama. }\end{array}$ \\
\hline \multirow[t]{2}{*}{3.} & \multirow[t]{2}{*}{$\begin{array}{l}\text { Sikap siswa } \\
\text { terhadap } \\
\text { pembelajaran } \\
\text { dengan } \\
\text { menggunakan } \\
\text { Pendekatan } \\
\text { Kontekstual }\end{array}$} & $\begin{array}{l}\text { Menunjukkan minat } \\
\text { terhadap pelajaran fisika } \\
\text { dengan pendekatan } \\
\text { kontekstual }\end{array}$ & 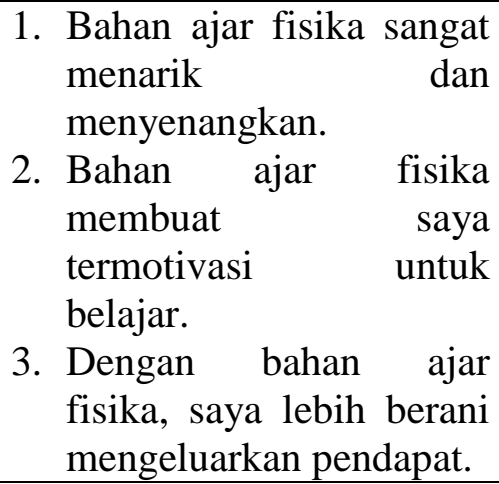 \\
\hline & & $\begin{array}{l}\text { Menunjukkan manfaat } \\
\text { mengikuti pembelajaran } \\
\text { fisika dengan pendekatan } \\
\text { kontekstual }\end{array}$ & $\begin{array}{l}\text { 1. Didalam bahan ajar } \\
\text { fisika banyak kegiatan } \\
\text { diskusi yang membuat } \\
\text { saya takut } \\
\text { mengungkapkan } \\
\text { pendapat } \\
\text { 2. Bahan ajar fisika dapat } \\
\text { menghilangkan } \\
\text { kesalahpahaman materi } \\
\text { pada diri saya } \\
\text { 3etode yang digunakan } \\
\text { dalam bahan ajar ini } \\
\text { memudahkan saya untuk } \\
\text { memahami materi. } \\
\text { 4. Saya senang dengan } \\
\text { pembelajaran } \\
\text { menggunakan bahan ajar } \\
\text { fisika karena ada praktik } \\
\text { langsung dan diskusi } \\
\text { kelompok. } \\
\text { 5. Saya senang dengan } \\
\text { pembelajaran dengan } \\
\text { menggunakan bahan ajar } \\
\text { karena bisa menyatakan } \\
\text { maksud soal dalam } \\
\text { bentuk simbol-simbol }\end{array}$ \\
\hline
\end{tabular}




\begin{tabular}{|c|c|c|c|}
\hline No & Aspek & Indikator & Pernyataan \\
\hline & & & $\begin{array}{l}\text { fisika sehingga saya } \\
\text { lebih mudah } \\
\text { menyelesaikannya } \\
\text { 6. Dengan adanya bahan } \\
\text { ajar fisika saya dapat } \\
\text { mengidentifikasi dan } \\
\text { menuliskan apa yang } \\
\text { diketahui dan ditanya } \\
\text { dari soal tersebut } \\
\text { 7. Dengan adanya bahan } \\
\text { ajar saya dapat } \\
\text { memberikan kesimpulan } \\
\text { terkait dengan soal yang } \\
\text { telah saya kerjakan. }\end{array}$ \\
\hline
\end{tabular}

\section{METODE PENELITIAN}

Metode penelitian merupakan cara ilmiah untuk mendapatkan data dengan tujuan dan kegunaan tertentu (Sugiyono, 2015). Arikunto (2010: 191), metode penelitian ilmiah cara kerja yang digunakan dalam melakukan suatu penelitian. Jenis penelitian yang digunakan adalah kuantitatif dengan metode penelitian eksprimen (Eksperimen Research). Pada penelitian ini menggunakan desain bentuk one-group pre-test - post-test design.Dalam desain ini tes dilakukan sebanyak dua kali yaitu sebelum dan sesudah perlakuan. Arikunto (2010: 124), desain penelitian dapat dilihat pada tabel Tabel 2 (Sugiyono, 2012:76).

Tabel 2 Desain Penelitian One-group pre-test-post-test design

\begin{tabular}{|c|c|c|}
\hline Pre-Test & Treatment & Post-Test \\
\hline $\boldsymbol{O}_{1}$ & $\mathrm{X}$ & $\mathrm{O}_{2}$ \\
\hline
\end{tabular}

$\mathrm{O}_{1}$ adalah Tes Awal (Pre-test), $\mathrm{O}_{2}$ adalah Tes Akhir (Post-test) dan $\mathrm{X}$ adalah perlakuan dengan menggunakan buku ajar berbasis kontektual.

Penelitian dilakukan di SMA Negeri 6 Model Lubuklinggau. Populasi dalam penelitian ini adalah seluruh siswa kelas XI, sedangkan sampel yang digunakan dalam penelitian ini adalah siswa kelas XI IPA 4 terdiri 23 siswa yang terdiri 14 perempuan dan 9 laki-laki. Teknik pengambilan sampel yang digunakan dalam penelitian ii adalah purposive sampling. Teknik pengumpulan data terdiri atas sebagai berikut: Observasi, kuesioner atau angket, wawancara, tes. Tujuan utama angket ini adalah untuk mengetahui respon siswa dan untuk menentukan kepraktisan buku ajar fisika berbasis kontekstual pada materi fluida statis di SMA Negeri 6 Model Lubukinggau tahun pelajaran 2018/2019.

Data dianalisis menggunakan uji hipotesis. Sugiyono (2012: 96) menyatakan bahawa hipotesis merupakan jawaban sementara terhadap rumusan masalah, dimana rumusan masalah penelitian telah dinyatakan dalam bentuk kalimat pertanyaan. Uji hipotesis menggunakan uji t, Sugiyono (2012: 250) dinyatakan persamaan rumus sebagai berikut: 


$$
\mathrm{t}=\frac{\bar{x}-\mu_{0}}{\frac{s}{\sqrt{n}}}
$$

Keterangan:

$\mathrm{t}=$ Nilai $\mathrm{t}$ yang dihitung

$\bar{x}=$ Rata-rata $x_{i}$

$\mu_{\circ}=$ Nilai yang dihipotesiskan

$s=$ Simpangan baku

$n=$ Jumlah anggota sampel

\section{HASIL DAN PEMBAHASAN}

Penelitian ini bertujuan untuk menentukan efektivitas buku ajar fisika berbasis kontekstual pada materi fluida statis. Variabel terikat dalam penelitian ini terdiri dari kemampuan siswa dalam ranah kognitif yang dilihat dari penilaian berdasarkan nilai ulangan siswa siswi kelas XI IPA 4 dan ranah afektif yaitu penilaian sikap dalam praktikum dan ranah psikomotorik yaitu penilaian berdasarkan unjuk kerja dalam suatu percobaan atau praktikum. Kemudian dalam ranah afektif dan psikomotorik ini akan dinilai oleh observer dari program studi pendidikan fisika yang menilai siswa siswi kelas XI IPA 4 tersebut dan yang terakhir adalah respon siswa terhadap pembelajaran dan pelaksanaan tersebut dilakukan setelah kegaiatan belajar mengajar sudah selesai.

Setelah diterapkan Buku ajar Fisika berbasis kontekstual siswa mudah memahami antara teori dengan kehidupan yang nyata. buku ajar Fisika berbasis kontekstual hasilnya bisa merubah pola pikir anak bahwa Fisika itu bukan hanya rumus saja yang dipelajari bahwa Fisika juga banyak juga hubungan kehidupan yang nyata, dan Fisika tidak akan lepas dengan kehidupan sehari-hari bahwa sangat jelas dari definisi saja Fisika merupakan ilmu yang mempelajari tentang fonemena gejala alam.

Kemudian buku Fisika berbasis kontekstual lingkungan sekitar dimanfaatkan contohnnya aqua bekas dijadikan siswa-siswi untuk melakukan suatu eksperimen tentang tekanan hidrostatis, jadi siswa -siswi bisa mengetahui konsep yang selama ini yang mereka tidak tahu menjadi tahu serta buku ajar Fisika berbasis kontekstual pada materi fluida statis pada proses pembelajaran dilakukan suatu penyampaian atau membangun pengetahuan sebelum menyampaikan suatu apersepsi yaitu mengaitkan antara teori dengan kehidupan yang nyata dan uraian diatas merupakan salah satu fase konstruktivisme.

a. Ranah Kognitif

Setelah diterapkan bahan ajar Fisika berbasis kontekstual pada materi fluida statis bahwa didapatkan hasil persentase sebesar $86,95 \%$.

b. Ranah Afektif

Dalam kemampuan siswa pada ranah afektif setelah diterapkan buku ajar fisika berbasis kontekstual pada materi fluida statis didapatkan hasil bahwa sikap dalam paraktikum yang terdiri dari sikap ingin tahu, ketelitian, ketekunan dan tanggungjawab hasilnnya sangat baik data tersebut berdasarkan nilai presentase peserta didik dalam ranah afektif sebesar 89.40\% dengan kategori"Sangat Baik".

c. Ranah Psikomotorik

Setelah diterapkan buku ajar fisika berbasis kontekstual pada materi fluida statis pada ranah psikomotorik ini sudah baik serta model yang dipakai peneliti dalam ranah ini sangat sesuai dan juga salah satu pembelajaran kontekstual muncul pada ranah ini yaitu learning community bertujuan siswa dapat belajar secara berkelompok dan hasil persentase padah ranah ini sebesar $91,30 \%$. 
d. Respon Siswa terhadap Pembelajaran.

Hasil angket respon siswa secara keseluruhan terhadap pembelajaran dengan pendekatan kontekstual diperoleh persentase 91,07\% atau kategori sangat baik. Hal ini menunjukkan respon siswa kelas XI IPA 4 dengan menggunkan buku ajar berbasis kontekstual materi fluida statis sangat baik. Adapun hasil belajar dan respon pembelajaran siswa kelas XI IPA di SMA Negeri 6 Model Lubuklinggau tahun pelajaran 2018/2019 ditunjukkan pada Gambar 1.

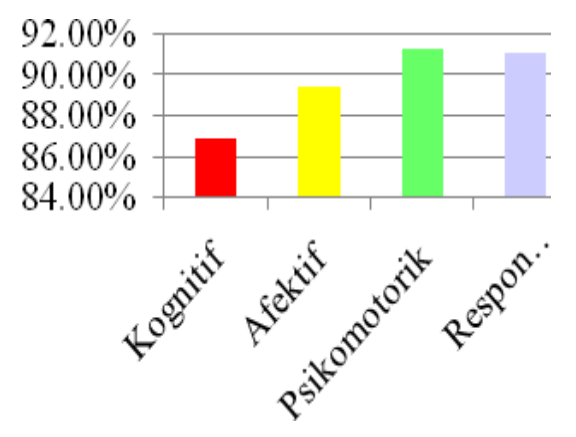

\section{Gambar 1. Diagram Hasil Persentase Efektivitas}

Berdasarkan nilai test ulangan harian kelas XI IPA 4 dengan jumlah siswa 23 yang terdiri dari 14 perempuan dan 9 laki-laki diperoleh hasil dari ulangan harian mereka adalah $86.95 \%$ dimana 20 siswa yang mendapatkan nilai di atas KKM yaitu 70 artinya siswa 20 siswa yang tuntas sedangkan 3 siswa mendapatkan nilai di bawah KKM. Persentase keafektifan sebesar $86,95 \%$ (sangat baik) sehingga dikatakan efektif. Yolanda (2014: 38) menyatakan CTL disebut sebagai pendekatan kontekstual karena konsep belajar membantu guru mengaitkan antara materi dengan situasi nyata dan mendorong siswa dengan membuat hubungan antara pengetahuan yang dimilikinya dengan penerapannya dalam kehidupan mereka sebagai masyarakat. Kemudian bukan hanya menurut Yolanda akan tetapi menurut penelitian terdahulu yakni Hosnan (2016: 267) menyatakan bahwa pembelajaran kontekstual merupakan konsep belajar dimana guru menghadirkan dunia nyata kedalam kelaas dan mendorong siswa membuat hubungan antara pengetahuan yang dimilikinya dengan penerapannya dalam kehidupan sehari-hari.

Kemudian hasil yang ditemukan peneliti dalam melakukan penelitian dalam melakukan mengembangkan buku ajar Fisika berbasis kontekstual didapatkan bahwa pada pembelajaran kontekstual mempunyai suatu kelebihan yaitu siswa lebih aktif dalam proses belajar mengajar kemudian siswa mudah memahami suatu konsep sehingga peserta didik bisa mengaplikasikan suatu teori dengan kehidupan nyata serta pembelajaran lebih bermakna dan siswa bukan dituntut menghapal sehingga daya ingat siswa terhadap materi tidak akan mudah lupa serta hasil belajar siswa meningkat karena proses kegiatan belajar mengajar menggunkan pembelajaran kontekstual yang mempunyai tujuh komponen penting dalam proses pembelajaran kontekstual yang membantu guru dan memudahkan seorang guru dalam mengajar.

Pembelajaran kontekstual ini sangat cocok sekali dalam mata pelajaran Fisika karena berdasarkan definisi Fisika bahwa ilmu yang mempelajari peristiwa atau gejala alam sehingga sesuai dengan diharapkan untuk mengaplikasikan suatu materi tersebut dengan kehidupan yang nyata sedangkan kekurangan pembelajaran kontekstual ini yang ditemukan peneliti dalam mengembangkan buku ajar tersebut bahwa pembelajaran kontekstual ini mempunyai suatu kekurangan yaitu guru tidak lagi sebagai pusat pembelajaran peserta didik karena setiap tujuh komponen pembelajaran kontekstual 
khususnnya pada komponen menemukan dan belajar kelompok yang sangat berperan penting menekankan siswa lebih aktif dan mandiri dalam kegiatan proses belajar mengajar. Berdasarkan uraian di atas, kelebihan dan kekurangan pada pembelajaran kontekstual yang ditemukan oleh peneliti mempunyai kesamaan dengan penelitian yang terdahulu bahwa pembelajaran kontekstua lebih efektif diterapkan di kelas. Hosnan (2014: 279) pembelajaran menjadi lebih bermakna dan real melalui CTL karena siswa dapat menangkap hubungan antara pengalaman belajar di sekolah dengan kehidupan yang nyata. Hal ini sangat penting, sebab dengan mengorelasikan materi yang ditemukan dalam kehidupan nyata, materi tersebut akan tertanam erat dalam memori siswa sehingga materi yang telah dipelajari tersebut tidak akan mudah dilupakan oleh siswa.

Pembelajaran lebih produktif dan mampu menumbuhkan penguatan konsep kepada siswa karena metode pembelajaran kontekstual menguat aliran konstuktivisme, dimana seorang siswa dituntut untuk menemukan pengetahuan sendiri. Melalui landasan filosofis konstruktivisme, siswa diharapkan belajar melalui "mengalami" bukan mengahapal.

\section{PENUTUP}

Berdasarkan hasil penelitian diperoleh kefektivan buku ajar fisika berbasis kontekstual pada materi fluida statis hasilnya yaitu presentase rata-rata siswa dalam ranah afektif sebesar $89,40 \%$ dan hasil presentase rata-rata siswa dalam ranah psikomotor sebesar 91.30\%. Presentase tes ulangan harian $86.95 \%$ siswa memperoleh nilai di atas 70 sehingga buku ajar fisika berbasis kontekstual pada materi fluida statis statis di SMA Negeri 6 Model lubuklinggau tahun pelajaran 2018/2019 semester ganjil dapat dikatakan efektif. Jadi dapat disimpulkan bahwa buku ajar fisika berbasis kontekstual pada materi fluida statis dapat dikatakan valid, praktis dan efektif sehingga buku ajar tersebut layak digunakan dalam proses belajar mengajar. Adapun beberapa hal yang dapat disarankan oleh penulis sebagai berikut:

1. Penulis menyarankan buku ajar Fisika berbasis kontekstual dapat digunakan dalam pembelajaran materi Fluida Statis karena telah mendapatkan nilai penilaian sangat baik dan layak digunakan.

2. Buku ajar Fisika berbasis kontekstual dapat juga dikolaborasikan dengan model pembelajaran yang lain selama menyertakan tujuh komponen penting dalam pembelajaran kontekstual.

\section{REFERENSI}

Afriani, A. (2018). Pembelajaran Kontekstual (Cotextual Teaching and Learning) dan Pemahaman Konsep Siswa. Jurnal Al-Mutaaliyah: Jurnal Pendidikan Guru Madrasah Ibtidaiyah, 3(1), 80-88.

Arikunto, S. (2010). Prosedur Penelitian Suatu Pendekatan Praktik. Jakarta: Rineka Cipta

Baroh, C. (2010). Efektivitas Metode Slumulasi dalam Pembelajaran Matematika Pada Pokok Bahasan Peluang di Kelas IX-A MTs Nurul Huda Kalanganyar Sedati Sidoarjo. Skripsi Pendidikan Matematika. Thesis, IAIN Sunan Ampel Surabaya.

Fahrudin, A. (2018). Development of Physics Summary Book as a Smartphone-Based Application and Its Effect on Elasticity Learning Achievement. Kasuari: Physics Education Journal (KPEJ), 1(1), 22-33.

Gumay, O. P. U., Kodarsih, E., \& Mulyanto, A. B. (2016). Pengaruh Model Pembelajaran Kooperatif Tipe Student Teams Achievement Division (STAD) Terhadap Hasil Belajar Fisika Siswa Kelas X SMA Negeri 2 Muara Beliti Tahun 
Pelajaran 2015/2016. In Prosiding Seminar Nasional Fisika (E-Journal) (Vol. 5, pp. SNF2016-EER).

Hosnan, M. (2016). Pendekatan Saintifik dan Kontekstual Dalam Pembelajaran Abad 21. Bogor: Ghalia Indonesia.

Jihad \& Haris.(2012). Evaluasi Pembelajaran. Yogyakarta: Multi Pressindo

Johnson, B Elaine. (2009). Contextual Teaching \& Learning. California: Corwin Press

Kasmadi \& Nia Siti Sunariah. (2013). Panduan Modern Penelitian Kuantitatif. Bandung: Alfabeta.

Komalasari, Kokom. (2010). Pembelajaran Kontekstual Konsep dan Aplikasi. Bandung: PT Refika Aditama

Nashar. (2004). Peranan Motivasi dan Kemampuan Awal. Jakarta: Delia Press

Nurfaidah., Junarti., \& Rizal. (2017). Meningkatkan Hasil Belajar Siswa melalui Pembelajaran Kooperatif Berbantuan Media Gambar di Kelas IV SD Inpres 15 Wara Pantoloan. Jurnal Kreatif Tadulako Online. 5(5).

Pratam, M.A., Mohamad A \& Endang S. (2016). Pengembangan Buku Ajar Matakuliah Biokteknologi di Universitas Jember.

Sanjaya, Wina. (2008). Perencanaan \& Desain Sistem Pembelajaran. Jakarta: Kencana Prenada Media Group.

Sugiyono. (2015). Metode Penelitian Kuantitatif Kualitatif dan R\&D. Bandung: Alfabeta

Widyaningsih, S. W., \& Yusuf, I. (2018). Project Based Learning Model Based on Simple Teaching Tools and Critical Thinking Skills. Kasuari: Physics Education Journal (KPEJ), 1(1), 12-21.

Yolanda, Y., \& Amin, A. (2018). Profil Keterampilan Proses Sains Fisika Siswa SMA di Kota Lubuklinggau pada Pokok Bahasan Listrik Dinamis. Thabiea: Journal of Natural Science Teaching, 1(2), 70-78. 